\title{
ASPECTS OF THE ECOLOGY OF PHLEBOTOMINES (Diptera: Psychodidae: Phlebotominae) IN AN AREA OF CUTANEOUS LEISHMANIASIS OCCURRENCE, MUNICIPALITY OF ANGRA DOS REIS, COAST OF RIO DE JANEIRO STATE, BRAZIL
}

\begin{abstract}
SUMMARY
Over a complete two-year period, phlebotomine specimens were caught in an area of cutaneous leishmaniasis occurrence in the municipality of Angra dos Reis. A manual suction tube was used to catch phlebotomines on house walls, and also light traps in domestic and peridomestic settings and in the forest. This yielded 14,170 specimens of 13 species: two in the genus Brumptomyia and eleven in the genus Lutzomyia. L. intermedia predominantly in domestic and peridomestic settings, with little presence in the forest, with the same trend being found in relation to $L$. migonei, thus proving that these species have adapted to the human environment. $L$. fischeri appeared to be eclectic regarding location, but was seen to be proportionally more endophilic. L. intermedia and $L$. migonei were more numerous in peridomestic settings, throughout the year, while $L$. fischeri was more numerous in domestic settings except in March, April, May and September. From the prevalence of L. intermedia, its proven anthropophily and findings of this species naturally infected with Leishmania (Viannia) braziliensis, it can be incriminated as the main vector for this agent of cutaneous leishmaniasis in the study area, especially in the peridomestic environment. L. fischeri may be a coadjuvant in carrying the parasite.
\end{abstract}

KEYWORDS: Phlebotomines; Cutaneous Leishmaniasis; Angra dos Reis.

\section{INTRODUCTION}

The present study is the first of an intended series on the ecology of phlebotomines in areas of cutaneous leishmaniasis occurrence in the Serra do Mar, i.e. the coastal mountain range of the states of Rio de Janeiro and São Paulo.

The traditional communities present in the study area are characterized by their development of subsistence agriculture, non-mechanized fishing and a variety of differentiated economic activities that came to be introduced into their day-to-day lives after the opening of the Rio-Santos highway (BR 101), which facilitated growth of tourism and real-estate speculation. Consequently, these communities present low income and schooling levels, minimal access to the official healthcare network and a particular absence of adequate participation in the local economy ${ }^{4}$.

Land occupation has been driven by individuals coming in from more highly valued parts of the region and has generally taken place in a non-harmonious manner. Thus, over recent decades, this has favored proliferation of areas at risk of Leishmania infection. Consequently, phlebotomine species that have already adapted to domestic and peridomestic environments can transmit the parasite to domestic animals, which serve as reservoirs ${ }^{4}$.
Changes to the environment in many regions of Brazil have modified the epidemiological profile of leishmaniasis. Thus, wild mammals that are reservoirs for Leishmania have been able to invade peridomestic areas that are populated by phlebotomine species that have become adapted to environments modified by humans. Maintenance of cutaneous leishmaniasis in these ecologically altered areas clearly indicates that a cycle of secondary transmission in the peridomestic environment has evolved $^{19,23}$.

Currently, cutaneous leishmaniasis presents three characteristic epidemiological patterns: wild, occupational and leisure. In addition, it has rural and periurban characteristics relating to the migratory process, in which hill slopes have been occupied, with transformation of forested land to secondary and residual forests. In the states of Rio de Janeiro and São Paulo, L. intermedia s. lat. has been the vector, especially in settings of intense human action, affecting individuals of both sexes in the domestic environment ${ }^{31}$.

In view of the diversity of phlebotomine species and the peculiarities of the areas involved, with or without transmission of cutaneous leishmaniasis, studies on the bioecology of species that have been shown to be vectors or are suspected of being vectors can be expected to provide useful information for constructing indicators that contribute towards 


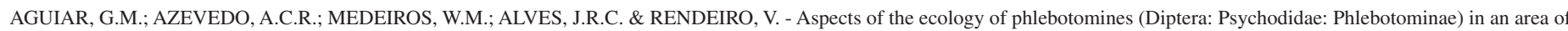
cutaneous leishmaniasis occurrence, municipality of Angra dos Reis, coast of Rio de Janeiro State, Brazil. Rev. Inst. Med. Trop. Sao Paulo, 56(2): $143-9,2014$.

risk assessment, thereby giving rise to prevention and control measures that are more effective.

With the aim of learning more about the habits of phlebotomines, a series of captures was undertaken. The objectives were to determine the local phlebotomine fauna, the behavior of the main species (endophilic or exophilic), their monthly frequencies and occurrence in domestic and forested environments.

\section{MATERIAL AND METHODS}

Study area: The municipality of Angra dos Reis is situated in the Rio de Janeiro State (23 $3^{\circ} 9^{\prime} 27^{\prime \prime} \mathrm{S}$ and $44^{\circ} 15^{\prime} 52^{\prime \prime} \mathrm{W}$ ) and is $155 \mathrm{~km}$ from the state capital. It is one of the oldest settled areas on the coast of the state of Rio de Janeiro and on the entire Atlantic coastline of Brazil, occupying a narrow strip of land between the bay of Ilha Grande and the escarpment of the Serra do Mar (the coastal mountain range). Angra is a word in Portuguese meaning "wide-open cove or small bay that appears where the land rises high above the shoreline" (Fig. 1).

The climate is hot and humid, with a rainy season in the summer. The mean annual rainfall is $2,279 \mathrm{~mm}$, but this is not evenly distributed over the year ${ }^{24}$.

The peninsula of Angra dos Reis was discovered in 1502 and because of its natural beauty and strategic position, it became a privileged and sought-after space, both as the state capital and as the private enterprise capital. Within this context, three major projects were implemented: the nuclear power complex, the terminal of the bay of Ilha Grande (TEBIG) and the Rio-Santos coastal highway (BR 101). Of these, the construction of the highway, which crosses the entire length of the municipality, was the greatest cause of the transformations, both at a social and at an environmental level ${ }^{26}$.

A house in the Camorim district of the municipality of Angra dos Reis was chosen to serve as a vector capture station. This house was selected because two cases of cutaneous leishmaniasis had been found in the family living there, and because it was suitable for systematized phlebotomine capture, given that it had outhouses for domestic animals and a banana plantation, and was relatively close to the forest.

Every month from March 1996 to February 1998, the investigators spent two nights in the study area. Phlebotomines that landed on both the internal and the external walls of the house were caught using manual suction tubes between the following hours: 18:00 to 20:00, 21:00 to 23:00 and 00:00 to 02:00. A total of 288 hours were spent on this activity. The CDC light traps (a total of three), were also installed inside the home, in the peridomestic area (next to the chicken coop) and in the forest (around 300 meters from the house), always at the same sites and same times (18:00 to 06:00 the next morning) and one $\mathrm{m}$ above the ground. The traps were in position for a total of 576 hours at each collection site.

To analyze the monthly frequencies of the most numerous species at the three collection sites, the Williams mean $\left(\mathrm{X}_{\mathrm{W}}\right)$ was calculated as described by HADDOW ${ }^{17,18}$. The numbers of phlebotomines caught inside the house (internal walls and light traps) in the peridomestic area (external walls and light traps) and in the forest (light traps) were summed.

\section{RESULTS}

For two consecutive years, by summing up the results each month, 14,170 phlebotomines of 13 species were caught. There were two species of the genus Brumptomyia França \& Parrot 1921 and eleven of the genus Lutzomyia França 1924 as listed in the following, in order of frequency, using the designations of YOUNG \& DUNCAN ${ }^{34}$ :

Lutzomyia (Nyssomyia) intermedia (Lutz \& Neiva, 1912)

Lutzomyia (Pintomyia) fischeri (Pinto, 1926)

Lutzomyia migonei (França, 1920)

Lutzomyia (Nyssomyia) whitmani (Antunes \& Coutinho, 1939)

Lutzomyia (Pintomyia) pessoai (Coutinho \& Barretto, 1940)

Lutzomyia monticola (Costa Lima, 1932)

Lutzomyia (Psychodopygus) ayrozai (Barretto \& Coutinho, 1940)

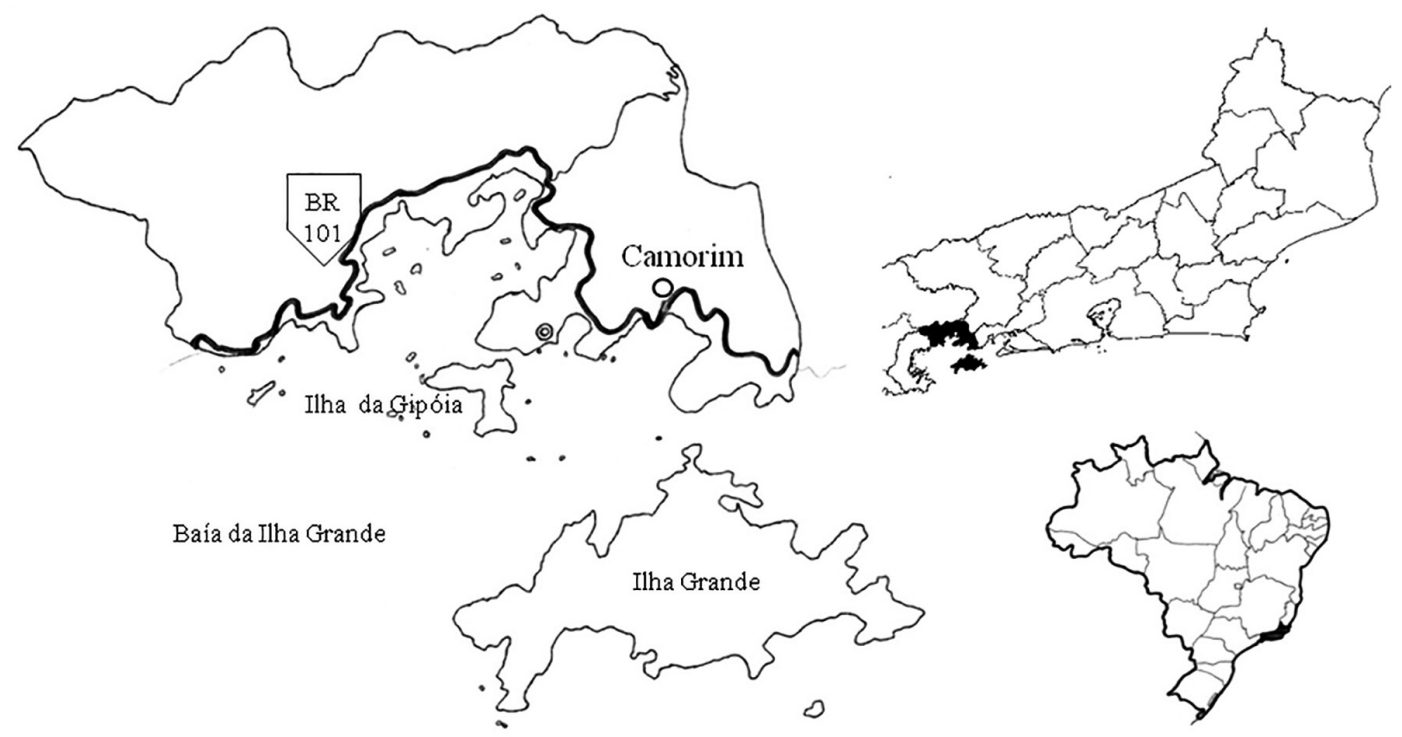

Fig. 1 - Map showing the location of the study area, in the Camorim district of the municipality of Angra dos Reis, state of Rio de Janeiro, Brazil. 


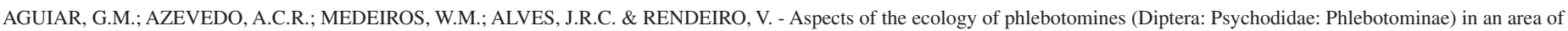
cutaneous leishmaniasis occurrence, municipality of Angra dos Reis, coast of Rio de Janeiro State, Brazil. Rev. Inst. Med. Trop. Sao Paulo, 56(2): 143-9, 2014.

Lutzomyia (Psathyromyia) shannoni (Dyar, 1929)

Lutzomyia edwardsi (Mangabeira, 1941)

Lutzomyia barrettoi (Mangabeira, 1942)

Brumptomyia avellari (Costa Lima, 1932)

Lutzomyia aragaoi (Costa Lima, 1932)

Brumptomyia guimaraesi (Coutinho \& Barretto, 1941)

Table 1 presents the monthly frequencies of the species L. intermedia, L. fischeri, L. migonei and L. whitmani, which together accounted for $99.6 \%$ of the total number of specimens caught. The number of females was overall greater than the number of males: $57 \%$ versus $43 \%$. L . intermedia showed balanced division, with only slightly more females; $L$. migonei showed a significantly greater number of males, while $L$. fischeri showed a predominance of females. Regarding the specimens caught when they landed on the internal and external walls of the house, L. intermedia was seen to be proportionally more exophilic, such that $70 \%$ of the examples were collected from the external walls, while L. fischeri was more endophilic, such that $72 \%$ of its specimens were caught on the internal walls of the house. L. migone $i$ was seen to be clearly exophilic, such that $97 \%$ were on the external walls.

Among the phlebotomines caught using light traps, the predominance of $L$. intermedia was again greatest in the peridomestic area, with smaller numbers inside the house and a few specimens in the forest. L. fischeri presented similar numbers inside and outside the house. In the forest, it had much smaller number, but nonetheless it was the predominant species. At this collection site, the presence of L. whitmani was also noteworthy.

Also in relation to Table I and equally in Fig. 2, it was noted that the four most important species had higher mean numbers during the hot and humid period of the year, i.e. between October and January, with maximum peaks in December for $L$. intermedia and January for $L$. fischeri and L. migonei. The predominance of L. intermedia was clear in all months, both inside the house and in the peridomestic area. In the cooler and drier part of the year, from May to August, it presented a certain balance with $L$. fischeri, but from August onwards inside the house and from September onwards in the peridomestic area, the means gradually increased until reaching their maximum peak in December. Even though the means for L. fischeri were much lower than those of L. intermedia, L. fischeri showed significant presence inside the house, with means that gradually increased up to the maximum peak, in January. In the peridomestic area, the means were more balanced over the year, such that the presence of $L$. fischeri was usually slightly greater than that of L. migonei, except in the hot and humid period, when the latter predominated. In the forest, L. fischeri predominated except between April and July, when there was a balance with L. whitmani, which registered more significant means between December and February.

\section{DISCUSSION}

In the Americas, American cutaneous leishmaniasis is widespread, affecting all countries except for Uruguay and Chile ${ }^{16}$. In Brazil, this disease extends across all states of the federation, with a tendency towards urban areas. Its extent is especially related to environmental changes introduced through human action, in areas of continuous population flow, especially in areas with high levels of tourism such as the region of the Green Coast, i.e. the coastline of the states of Rio de Janeiro and São Paulo ${ }^{3}$.
In the southeastern region of Brazil, a process of geographical expansion of the endemic area of cutaneous leishmaniasis has been witnessed. This has probably taken place as a result of the introduction of the parasite into new areas by means of migration of infected people and domestic animals $\mathrm{s}^{4,12,22,27,28}$.

In most areas with Leishmania (Viannia) braziliensis transmission in the southeastern and northeastern regions of Brazil, there is absolute predominance of L. intermedia or L. whitmani, followed by L. fischeri and L. migonei, in domestic environments ${ }^{10,13,29,30,33}$.

FORATTINI \& OLIVEIRA ${ }^{14}$ raised the hypothesis that L. intermedia s. lat. (intermedia complex formed by L. intermedia s. str. and L. neivai) was the main transmitter of Leishmania braziliensis, while GOMES et $a l .{ }^{15}$ corroborated the suspicions of FORATTINI et al. ${ }^{13}$ that this species carried the parasite in periurban areas.

Lutzomyia intermedia (Lutz \& Neiva 1912) and L. neivai (Pinto 1926) are captured in various parts of Brazil and show a remarkable intraspecific and intrapopulational variation gradient ${ }^{7}$. L. neivai was considered synonymous junior of $L$. intermedia ${ }^{21}$, both with allopatric distribution in regions west of the Serra do Mar, in the states of São Paulo and Paraná and sympatric speciation in the Serra do Mar, in the state of São Paulo ${ }^{6,20}$.

American cutaneous leishmaniasis acquired epidemic characteristics on the northern coastline of the State of São Paulo beginning in the 1990s. From secondary data, a descriptive study of the disease in the four municipalities making up this region over the period from 1993 to 2005 was conducted. The frequency of phlebotomine capture in the probable transmission locations was analyzed. Among the 2,758 phlebotomines captured, Lutzomyia intermedia s. lat. predominated (80.4\%) inside homes and in areas surrounding them ${ }^{11}$.

In 1978, ARAÚJO FILHO ${ }^{8}$ studied an outbreak of the disease in Ilha Grande, state of Rio de Janeiro and showed that L. intermedia predominated over the other species. On that occasion, this author reported that L. flaviscutelatta, the vector for Leishmania amazonensis, was present.

AGUIAR et al. $^{4}$ studied the phlebotomine fauna of Paraty, a municipality on the coast of the state of Rio de Janeiro and took the view that $L$. intermedia could be considered to be a potential vector for Leishmania braziliensis, given its high prevalence, anthropophilic nature and high degree of eclectic behavior, as well as because this species had already been incriminated in other areas of the southeastern region of Brazil. The insignificant presence of this species in wild environments and its adaptation to environments modified by humans led these authors to conclude that $L$. intermedia was transmitting the parasite in domestic and peridomestic settings.

AZEREDO-COUTINHO et al. ${ }^{9}$ reported on an unusual case of human infection by Leishmania amazonensis that occurred in the historical city of Paraty. This species, which typically occurs in Amazônia, had already been identified in the states of Goiás, Mato Grosso, Bahia, Minas Gerais, São Paulo, Paraná and Santa Catarina, and it was also recently held responsible for the development of an autochthonous case of diffuse cutaneous leishmaniasis, which is a rare and severe form of the disease $\mathrm{e}^{9,31}$. 


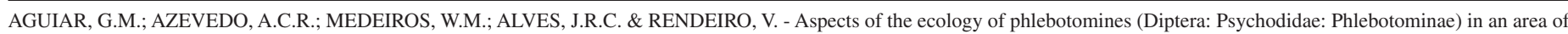
cutaneous leishmaniasis occurrence, municipality of Angra dos Reis, coast of Rio de Janeiro State, Brazil. Rev. Inst. Med. Trop. Sao Paulo, 56(2): 143-9, 2014.

Table 1

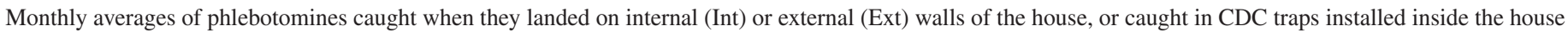

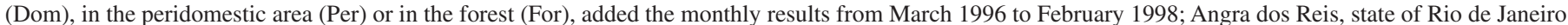

\begin{tabular}{|c|c|c|c|c|c|c|c|c|c|c|c|c|c|c|c|c|}
\hline \multirow{3}{*}{ Spe } & \multirow{3}{*}{\multicolumn{2}{|c|}{ Local }} & \multirow{3}{*}{ Sex } & \multicolumn{12}{|c|}{ Years/Months } & \multirow{3}{*}{ Total } \\
\hline & & & & \multicolumn{10}{|c|}{$1996-97$} & \multicolumn{2}{|c|}{$1997-98$} & \\
\hline & & & & Mar & Apr & May & Jun & Jul & Aug & Sep & Oct & Nov & Dec & Jan & Feb & \\
\hline \multirow{10}{*}{ 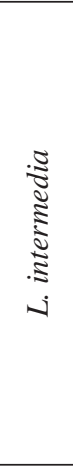 } & \multirow{4}{*}{$\overline{\bar{\pi}}$} & \multirow{2}{*}{ Int } & $\mathrm{F}$ & 76 & 24 & 16 & 19 & 34 & 27 & 62 & 65 & 79 & 134 & 191 & 125 & 838 \\
\hline & & & M & 11 & 8 & - & - & - & 1 & 3 & 7 & 15 & 23 & 13 & 18 & 113 \\
\hline & & \multirow{2}{*}{ Ext } & $\mathrm{F}$ & 267 & 75 & 62 & 56 & 44 & 59 & 66 & 76 & 128 & 203 & 239 & 182 & 1,457 \\
\hline & & & M & 127 & 33 & 19 & 17 & 24 & 28 & 30 & 32 & 84 & 126 & 168 & 172 & 860 \\
\hline & \multirow{6}{*}{ 己ِ } & \multirow{2}{*}{ Dom } & $\mathrm{F}$ & 115 & 45 & 35 & 23 & 44 & 46 & 97 & 93 & 144 & 194 & 135 & 146 & 1,117 \\
\hline & & & M & 12 & 4 & 3 & 1 & 1 & 7 & 21 & 47 & 63 & 94 & 78 & 53 & 384 \\
\hline & & \multirow{2}{*}{ Per } & $\mathrm{F}$ & 122 & 39 & 21 & 27 & 32 & 37 & 43 & 201 & 297 & 338 & 401 & 299 & 1,857 \\
\hline & & & $\mathrm{M}$ & 289 & 114 & 81 & 89 & 62 & 68 & 93 & 321 & 524 & 708 & 416 & 326 & 3,091 \\
\hline & & \multirow{2}{*}{ For } & $\mathrm{F}$ & - & - & - & - & 1 & 1 & - & - & - & - & - & - & 2 \\
\hline & & & $\mathrm{M}$ & - & - & 1 & - & 1 & - & - & - & - & 2 & - & - & 4 \\
\hline \multirow{10}{*}{$\frac{\tilde{J}}{\tilde{J}}$} & \multirow{4}{*}{$\stackrel{\bar{\Xi}}{\overline{3}}$} & \multirow{2}{*}{ Int } & $\mathrm{F}$ & 11 & 24 & 14 & 22 & 35 & 46 & 35 & 59 & 48 & 84 & 65 & 54 & 497 \\
\hline & & & $\mathrm{M}$ & - & - & - & - & 1 & 1 & - & - & - & 1 & 2 & - & 5 \\
\hline & & \multirow{2}{*}{ Ext } & $\mathrm{F}$ & 7 & 10 & 9 & 4 & 15 & 10 & 26 & 10 & 19 & 32 & 29 & 20 & 191 \\
\hline & & & $\mathrm{M}$ & 1 & - & - & - & 2 & 2 & 3 & 5 & 4 & 4 & 3 & 5 & 29 \\
\hline & & & $\mathrm{F}$ & 34 & 16 & 5 & 12 & 4 & 9 & 38 & 81 & 114 & 147 & 283 & 181 & 924 \\
\hline & & Dom & $\mathrm{M}$ & 2 & - & - & 1 & - & - & 6 & 3 & 8 & 7 & 3 & 8 & 38 \\
\hline & U & & $\mathrm{F}$ & 84 & 40 & 36 & 18 & 16 & 31 & 56 & 71 & 79 & 83 & 88 & 53 & 655 \\
\hline & $\theta$ & Per & $\mathrm{M}$ & 13 & 3 & 2 & 3 & - & 5 & 29 & 26 & 35 & 44 & 51 & 38 & 249 \\
\hline & & & $\mathrm{F}$ & 23 & 3 & - & 2 & 1 & 2 & 9 & 17 & 20 & 34 & 21 & 18 & 150 \\
\hline & & For & $\mathrm{M}$ & 29 & 4 & 1 & 3 & 1 & 4 & 13 & 19 & 21 & 42 & 31 & 26 & 194 \\
\hline & & Int & $\mathrm{F}$ & - & - & - & 1 & - & 1 & - & - & 3 & 1 & 1 & - & 7 \\
\hline & స & IIIt & $\mathrm{M}$ & - & - & - & - & - & - & - & - & - & - & 1 & 1 & 2 \\
\hline & 3 & & $\mathrm{~F}$ & 6 & 2 & 2 & 1 & - & 2 & 7 & 4 & 16 & 32 & 14 & 24 & 110 \\
\hline & & EXt & $\mathrm{M}$ & 21 & 10 & 7 & 4 & 3 & 6 & 15 & 12 & 22 & 44 & 20 & 29 & 193 \\
\hline 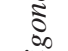 & & & $\mathrm{F}$ & 6 & 2 & - & 1 & - & 2 & 4 & 4 & 7 & 9 & 5 & 6 & 46 \\
\hline$\widetilde{\Xi}$ & & Dom & M & 3 & 1 & - & - & - & - & 2 & 1 & 4 & 5 & 3 & 7 & 26 \\
\hline$j$ & & & $\mathrm{~F}$ & 11 & 2 & - & 3 & 2 & 6 & 8 & 17 & 28 & 43 & 40 & 29 & 189 \\
\hline & 己 & Per & $\mathrm{M}$ & 38 & 7 & 5 & 16 & 8 & 11 & 20 & 47 & 79 & 155 & 185 & 124 & 695 \\
\hline & & For & $\mathrm{F}$ & - & - & - & - & - & - & 1 & - & - & - & - & - & 1 \\
\hline & & For & $\mathrm{M}$ & 2 & - & - & - & - & - & - & - & 1 & 1 & - & - & 4 \\
\hline & & & $\mathrm{F}$ & - & - & - & - & - & - & - & - & - & - & - & - & - \\
\hline & స & Int & $\mathrm{M}$ & - & - & - & - & - & - & - & - & - & - & - & - & - \\
\hline & 3 & Ext & $\mathrm{F}$ & - & - & - & - & - & - & - & - & - & - & - & - & - \\
\hline & & EXt & $\mathrm{M}$ & - & - & - & - & - & - & - & - & - & - & - & - & - \\
\hline$\stackrel{\mathbb{I}}{\Xi}$ & & Dom & $\mathrm{F}$ & - & - & - & - & - & - & - & - & - & - & - & - & - \\
\hline$\frac{\pi}{3}$ & & Dom & M & - & - & - & - & - & - & - & - & - & - & - & - & - \\
\hline$\dot{\jmath}$ & U & & $\mathrm{F}$ & 1 & - & - & - & - & - & 1 & 2 & - & 3 & 1 & 1 & 9 \\
\hline & 己 & Per & M & - & - & - & - & - & - & 2 & - & 1 & - & - & 1 & 6 \\
\hline & & & $\mathrm{F}$ & 7 & 5 & 3 & - & - & - & 1 & 4 & 5 & 16 & 12 & 10 & 63 \\
\hline & & For & M & 4 & 2 & 1 & 1 & 3 & 3 & 4 & 9 & 12 & 19 & 24 & 31 & 113 \\
\hline
\end{tabular}

L. = Lutzomyia Spe $=$ species. 

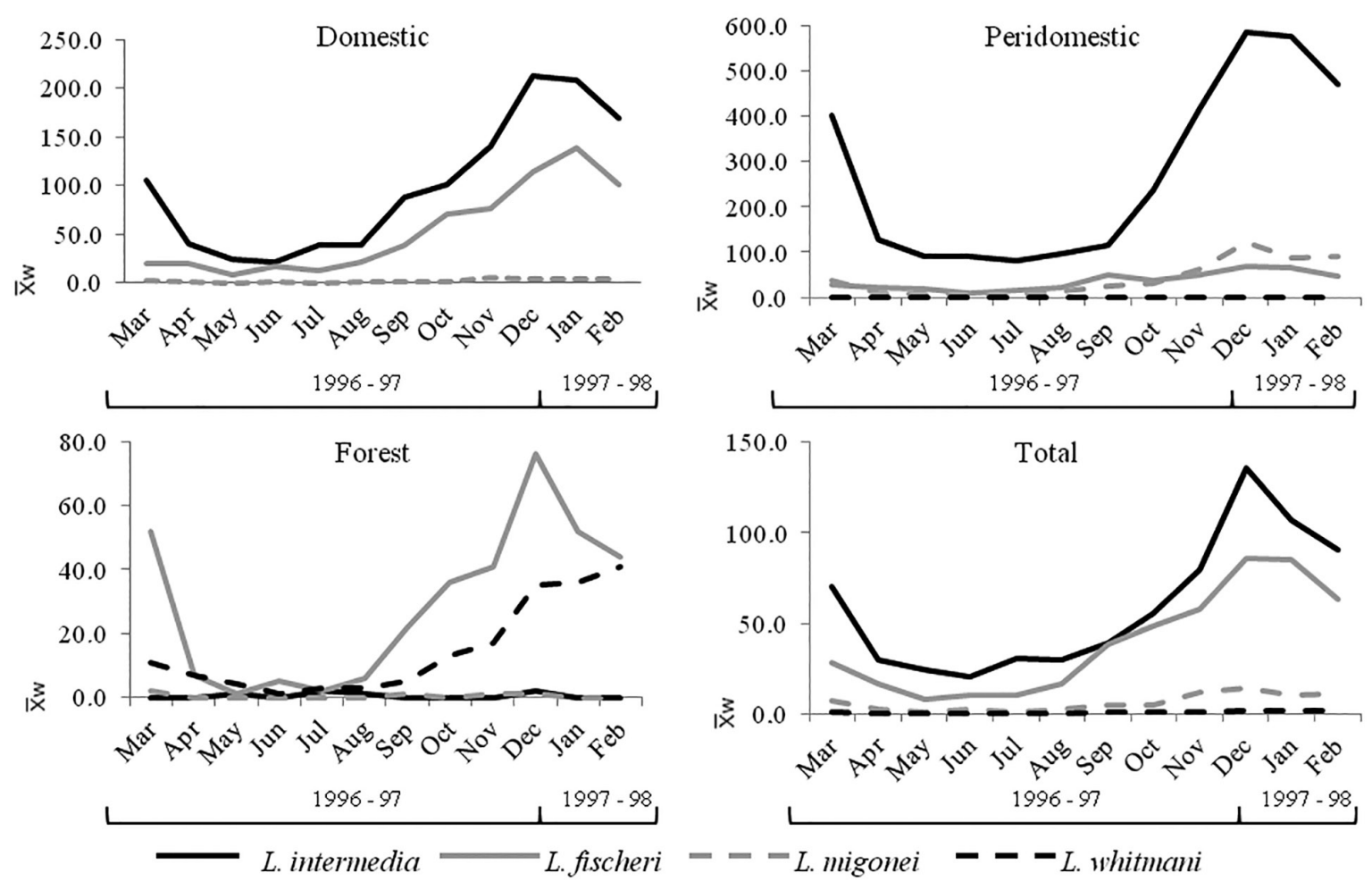

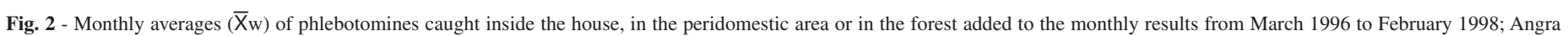
dos Reis, Rio de Janeiro State.

It is important to remember that in Brazil, human migrations to new agricultural areas and to urban centers have contributed towards propagating various diseases. Leishmaniasis is no different in this respect, given that large outbreaks of this disease have occurred especially in recently colonized areas. Thus, the changes to the natural environment caused by humans have had a huge impact on the behavior of the phlebotomine fauna, such that some species have disappeared while others have adapted to the human environment. Situations like this can be demonstrated in many foci of cutaneous leishmaniasis in the states of Rio de Janeiro, São Paulo and Paraná. In these regions that have been occupied for longer times, the environment changes were accompanied by adaptation of the components of the transmission cycle. In this manner, the changes induced selection of the phlebotomine species and reservoirs, which became better-fitted for survival under the new conditions represented by residual forests close to human homes in rural zones or on the periphery of urban zones with or without rural characteristics ${ }^{3,27,32}$.

As a consequence of the drastic changes to the environment caused by human interference, some wild mammals that are reservoirs for Leishmania invaded domestic areas in which some phlebotomine species with eclectic feeding habits could be found. Through this, a transmission cycle with the potential to affect humans was established ${ }^{28,32}$.

From research carried out so far in the southeastern and southern regions of Brazil, it can be said that $L$. neivai and L. migonei are the phlebotomine species with the greatest capacity for adaptation to human environments and therefore have the greatest possibility of adaptation to the domestic environment. The proof of this is the ever smaller numbers of specimens found in forested areas. Another important factor is the male/female ratio in the peridomestic environment, which suggests that the natural shelters and breeding sites of these species are nearby, given that, as is well known, the males do not have much capacity for flight and appear in large numbers in the peridomestic area motivated by mating 5 . However, in the district of Posse, in a rural zone of the municipality of Petrópolis, at a distance of $112 \mathrm{~km}$ from the city of Rio de Janeiro, and in the municipality of Mesquita, a periurban region on the Gericinó massif, state of Rio de Janeiro, investigations demonstrated that L. intermedia also occurred in significant numbers in the residual forests. In Mesquita, a hypothesis of three transmission cycles was also formulated (domestic, extradomestic and wild). The authors highlighted the sloth as a possible reservoir for Leishmania braziliensis, which would act as a link between the wild and peridomestic environments, while dogs and horses would participate in the domestic cycle, with L. intermedia as the main vector ${ }^{23,32}$. However, in all the locations where this species predominates, the numbers reveal that there is greater activity in the domestic and peridomestic environments, thus proving the trend towards domestic adaptation of this species ${ }^{2}$.

Over the years, in Angra dos Reis, increasing devastation of the forest and growth of banana plantations (where the inhabitants frequently construct their houses, following a habit that started with the irregular division of the land into plots in the 1960s) have led to decreases in the phlebotomine and forest animal fauna. However, the density of $L$. intermedia in the domestic and peridomestic environments has increased: in these settings, survival of the species has been ensured through the close feeding relationship with humans and domestic and synanthropic animals. 


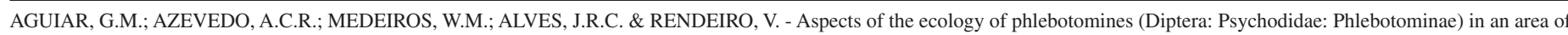
cutaneous leishmaniasis occurrence, municipality of Angra dos Reis, coast of Rio de Janeiro State, Brazil. Rev. Inst. Med. Trop. Sao Paulo, 56(2): $143-9,2014$.

In the study area, out of the 13 species obtained, six species $(L$. intermedia, L. migonei, L. fischeri, L. whitmani, L. pessoai and L. ayrozai) had already been found naturally infected with Leishmania braziliensis and Leishmania naiffi $i^{25,31}$. It has also been suggested that all of these species are transmitters in the epidemiological chain of cutaneous leishmaniasis and that they frequent both the domestic environment and remnant forest ${ }^{1,27,28}$.

The high prevalence of L. intermedia has also been proven. Even with negative data from investigation of natural infection, the adaptive capacity of L. intermedia to environments modified by humans and its proven anthropophily allows it to be suggested that this species can be incriminated as the main vector for Leishmania (Viannia) braziliensis and that the transmission takes place in the domestic/peridomestic environment.

In relation to monthly frequency, $L$. intermedia presented great predominance in all the months of the year, both in the domestic and in the peridomestic environment. There was a gradual increase in frequency over the hotter and more humid period (between October and January, with mean temperatures ranging from 26 to $29{ }^{\circ} \mathrm{C}$ and relative air humidity from 84 to $87 \%$. The maximum peak of activity was in December, whereas for L. fischeri and L. migonei, the highest peaks were in January.

The presence of L. fischeri in domiciliary environments, represented by much higher numbers of females, leads to the supposition that this species is not yet undergoing a process of domestic adaptation. Thus, it still maintains its natural shelters and breeding sites in the residual forest, as proven by the balance between the sexes at this study location, with slightly higher numbers of males. It can therefore be said that this species is eclectic regarding its blood meal location. Considering also that this species presented significant numbers at all three collection sites and that the distance from the house to the forest was around 300 meters, the data suggests that this is a species with greater dispersion.

Recently, in the municipality of Porto Alegre, in the state of Rio Grande do Sul, PITA-PEREIRA et al. ${ }^{25}$ found naturally infected $L$. fischeri specimens in a periurban area by means of the PCR technique. In the present study area, even though there were no observations of natural infection due to Leishmania sp., important epidemiological factors relating to L. fischeri were observed, especially its high anthropophily, degree of eclecticism and endophilia, along with levels of occurrence in foci of cutaneous leishmaniasis in the Brazilian Southeastern region that have always been notable. Hence, the results suggest that this species may act as a secondary vector for Leishmania braziliensis in the domestic/peridomestic environment. Since its population remains predominantly in the forest, it may participate in transmission within its natural enzootic cycle.

In relation to L. migonei, it was found that this species had greater adaptation to the peridomestic area, particularly in outhouses where domestic animals are kept. This was corroborated by the small number of specimens found in the forest, along with the greater presence of males in the peridomestic area. These factors demonstrate that this species is well adapted to environments that have been subjected to human influence.

Even with a small number of specimens, the presence of $L$. whitmani stood out. This species was only caught in light traps, and in more significant numbers in the forest. It has been recorded in the state of Rio de Janeiro at low rates, but in studies conducted in the municipality of Posse, state of Rio de Janeiro, SOUZA et al. ${ }^{32}$ the hypothesis that $L$. whitmani may be exerting pressure on the ecological niche of $L$. intermedia was raised.

\section{RESUMO}

\section{Aspectos da ecologia dos flebotomíneos (Diptera: Psychodidae: Phlebotominae) em área de ocorrência de leishmaniose tegumentar, Município de Angra dos Reis, orla marítima do estado do Rio de Janeiro, Brasil}

Durante dois anos completos foram feitas capturas de flebotomíneos em área de leishmaniose tegumentar no município de Angra dos Reis. Utilizou-se tubo de sucção manual, para as capturas dos flebotomíneos pousados nas paredes da casa, além de armadilhas luminosas, no domicílio, peridomicílio e na mata. Foram obtidos 14.170 exemplares, de treze espécies, duas do gênero Brumptomyia França \& Parrot 1921 e onze do gênero Lutzomyia França 1924. L. intermedia teve supremacia no peridomicílio e no domicílio, com pouca presença na mata, o mesmo ocorreu com L. migonei, comprovando a adaptação dessas espécies ao ambiente humano. L. fischeri aparece com característica eclética quanto ao local, mostrando-se proporcionalmente mais endófila. $L$. intermedia e L. migonei foram mais numerosas no peridomicílio, durante todos os meses do ano, enquanto L. fischeri, excetuando os meses de março, abril, maio e setembro, foi mais numerosa no domicílio. Pela prevalência, comprovada antropofilia e por ter sido encontrada infectada naturalmente por Leishmania (Viannia) braziliensis, L. intermedia pode ser incriminada como o principal vetor desse agente da leishmaniose tegumentar na área de estudo, sobretudo no ambiente peridomiciliar. $L$. fischeri, pelas características apresentadas, pode ser um coadjuvante na veiculação do parasita.

\section{REFERENCES}

1. Aguiar GM, Rendeiro V. Flebotomíneos (Diptera: Phlebotominae) em área de foco ativo de leishmaniose tegumentar, orla marítima do Estado do Rio de Janeiro, Brasil. In: $21^{\circ}$ Congresso Brasileiro de Entomologia; 2006 ago 6-11; Recife. Resumos. p. ID: 1231-1.

2. Aguiar GM, Medeiros WM. Distribuição regional e habitats das espécies de flebotomíneos do Brasil. In: Rangel EF, Lainson R, editores. Flebotomíneos do Brasil. Rio de Janeiro: Fiocruz; 2003. p. 207-55.

3. Aguiar GM, Medeiros WM, De Marco TS, Santos SC, Gambardella S. Ecologia dos flebotomíneos da Serra do Mar, Itaguaí, Estado do Rio de Janeiro, Brasil. I. A fauna flebotomínica e prevalência pelo local e tipo de captura (Diptera, Psychodidae, Phlebotominae). Cad Saude Publica. 1996;12:195-206.

4. Aguiar GM, Medeiros WM, Santos TG, Klein AFL, Ferreira VA. Ecology of sandflies in a recent focus of cutaneous leishmaniasis in Paraty, littoral of Rio de Janeiro State (Diptera, Psychodidae, Phlebotominae). Mem Inst Oswaldo Cruz. 1993;88:339-40.

5. Aguiar GM, Vilela ML. Aspects of the ecology of sandflies at the Serra dos Órgãos National Park, State of Rio de Janeiro. VI. Shelters and breeding places (Diptera, Psychodidae, Phlebotominae). Mem Inst Oswaldo Cruz. 1987;82:585-6.

6. Andrade Filho JD, Galati EAB, Falcão AL. Nyssomyia intermedia (Lutz \& Neiva, 1912) and Nyssomyia neivai (Pinto, 1926) (Diptera: Psychodidae: Phlebotominae) geographical distribution and epidemiological importance. Mem Inst Oswaldo Cruz. 2007;102:481-7. 
AGUIAR, G.M.; AZEVEDO, A.C.R.; MEDEIROS, W.M.; ALVES, J.R.C. \& RENDEIRO, V. - Aspects of the ecology of phlebotomines (Diptera: Psychodidae: Phlebotominae) in an area of cutaneous leishmaniasis occurrence, municipality of Angra dos Reis, coast of Rio de Janeiro State, Brazil. Rev. Inst. Med. Trop. Sao Paulo, 56(2): 143-9, 2014.

7. Andrade Filho JD, Galati EAB, Falcão AL. Polymorphism, inter-population and interspecific variation in Nyssomyia intermedia (Lutz \& Neiva) and Nyssomyia neivai (Pinto) (Diptera, Psychodidae, Phlebotominae). Rev Bras Entomol. 2006;50:385-93.

8. Araujo Filho NA. Epidemiologia da leishmaniose tegumentar americana na Ilha Grande, Estado do Rio de Janeiro, estudo sobre a infecção humana, reservatórios e transmissores. [dissertação]. Rio de Janeiro: Faculdade de Medicina Universidade Federal do Rio de Janeiro; 1978.

9. Azeredo-Coutinho RBG, Conceição-Silva F, Schubach A, Cupolillo E, Quintella LP, Madeira MF, et al. First report of diffuse cutaneous leishmaniasis and Leishmania amazonensis infection in Rio de Janeiro State, Brazil. Trans R Soc Trop Med Hyg. 2007;101:735-7.

10. Azevedo ACR, Rangel EF. A study of sandfly species (Diptera: Psychodidae: Phlebotominae) in a focus of cutaneous leishmaniasis in the municipality of Baturité, Ceará, Brazil. Mem Inst Oswaldo Cruz. 1991;86:405-10.

11. Condino MLF, Galati EAB, Holcman MM, Salum MRB, Silva DC, Novaes Júnior RA. Leishmaniose tegumentar americana no litoral norte paulista, período 1993 a 2005 Rev Soc Bras Med Trop. 2008;4:635-42.

12. Falqueto A. Especificidade alimentar de flebotomíneos em duas áreas endêmicas de leishmaniose tegumentar no Estado do Espírito Santo. [tese]. Rio de Janeiro: Instituto Oswaldo Cruz/Fundação Oswaldo Cruz; 1995.

13. Forattini OP, Rabello EX, Serra OP, Cotrim MD, Galati EAB, Barata JMS. Observações sobre a transmissão de leishmaniose tegumentar no Estado de São Paulo, Brasil. Rev Saude Publica. 1976;10:31-43.

14. Forattini OP, Oliveira DE. Um foco de leishmaniose tegumentar na zona sul do Estado de São Paulo, Brasil. Arq Fac Hig São Paulo. 1957;11:23-4.

15. Gomes AC, Rabello EX, Santos JLF, Galati EAB. Aspectos ecológicos da leishmaniose tegumentar americana. I. Estudo experimental da frequência de flebotomíneos a ecótopos artificiais com frequência especial a Psychodopygus intermedius. Rev Saude Publica. 1980;14:540-56.

16. Gontijo CMF, Melo MN. Leishmaniose visceral no Brasil: quadro atual, desafios e perspectivas. Rev Bras Epidemiol. 2004;7:338-49.

17. Haddow AJ. Studies on the biting habits and medical importance of east African mosquitoes in the genus Aedes. I. Subgenera Aedimorphus, Banksinella and Nunnius. Bull Entomol Res. 1960;50:759-79.

18. Haddow AJ. Studies on the biting habits of African mosquitoes: an appraisal of methods employed, with special reference to the twenty-four-hour catch. Bull Entomol Res. 1954;45:199-242.

19. Lainson R, Shaw JJ. New world leishmaniasis. The Neotropical Leishmania species. In: Cox FEG, Kreier JP, Wakelin D, editors. Topley \& Wilson's microbiology and microbial infections. $9^{\text {th }}$ ed. London: Hodder Arnold; 1998. vol. 5. Parasitology. p. 242-66.

20. Marcondes CB, Lozovei AL, Vilela JH. Distribuição geográfica de flebotomíneos do complexo Lutzomyia intermedia (Lutz \& Neiva, 1912) (Diptera, Psychodidae). Rev Soc Bras Med Trop. 1998,31:51-8.

21. Marcondes CB. A redescription of Lutzomyia (Nyssomyia) intermedia (Lutz \& Neiva, 1912), and ressurection of L. neivai (Pinto, 1926) (Diptera, Psychodidae, Phlebotominae). Mem Inst Oswaldo Cruz. 1996;91:457-62.
22. Marzochi MCA, Souza WJS, Coutinho SG, Toledo LM, Grimaldi Filho G, Momen H. Evolution of diagnostic criteria in human and canine mucocutaneous leishmaniasis in a Rio de Janeiro district where Leishmania braziliensis braziliensis occurs. In: $9^{\circ}$ Reunião Anual de Pesquisa Básica em Doença de Chagas; 1982 nov 8-10; Caxambu. Abstract 46. p. 63

23. Menezes CRV, Azevedo ACR, Costa SM, Costa WA, Rangel EF. Ecology of American cutaneous leishmaniasis in the State of Rio de Janeiro, Brazil. J Vector Ecol 2002;27:207-14

24. Nimer E. Climatologia da Região Sudeste: introdução à climatologia dinâmica. Rev Bras Geogr. 1972;34:3-48.

25. Pita-Pereira D, Souza GD, Pereira TA, Zwetsch A, Britto C, Rangel EF. Lutzomyia (Pintomyia) fischeri (Diptera: Psychodidae: Phlebotominae), a probable vector of American cutaneous leishmaniasis: detection of natural infection by Leishmania (Viannia) DNA in specimens from the municipality of Porto Alegre (RS), Brazil, using multiplex PCR assay. Acta Trop. 2011;120:273-5

26. Prefeitura de Angra dos Reis [homepage on the internet]. História do município [cited: 2012 Mar 16]. Available from: http://www.angra.rj.gov.br/asp/municipio/ muni_historia.asp

27. Rangel EF, Lainson R. Proven and putative vectors of American cutaneous leishmaniasis in Brazil: aspects of their biology and vectorial competence. Mem Inst Oswaldo Cruz. 2009; $104 \cdot 937-54$

28. Rangel EF, Lainson R. Ecologia das leishmanioses: transmissores de leishmaniose tegumentar americana. In: Rangel EF, Lainson R, editores. Flebotomíneos do Brasil Rio de Janeiro: Fiocruz; 2003. p. 291-310.

29. Rangel EF, Barbosa AF, Andrade CA, Sousa NA, Wermelinger ED. Development of Leishmania (Viannia) braziliensis (Vianna, 1911) in Lutzomyia intermedia (Lutz \& Neiva, 1912) (Diptera: Psychodidae: Phlebotominae) under experimental conditions. Mem Inst Oswaldo Cruz. 1992;87:235-8.

30. Rangel EF, Azevedo AC, Andrade CA, Souza NA, Wermelinger ED. Studies on sandfly fauna (Diptera: Psychodidae) in a foci of cutaneous leshmaniasis in Mesquita, Rio de Janeiro State, Brazil. Mem Inst Oswaldo Cruz. 1990;85:39-45.

31. Secretaria de Vigilância em Saúde. Ministério da Saúde. Manual de vigilância da leishmaniose tegumentar americana. $2^{\text {nd }}$ ed. Brasília: Ministério da Saúde; 2007.

32. Souza NA, Andrade-Coelho CA, Vilela ML, Peixoto AA, Rangel EF. Seasonality of Lutzomyia intermedia and Lutzomyia whitmani (Diptera: Psychodidae Phlebotominae), occurring sympatrically in area of cutaneous leishmaniasis in the State of Rio de Janeiro, Brazil. Mem Inst Oswaldo Cruz. 2002;97:759-65

33. Souza NA, Andrade-Coelho CA, Vilela ML, Rangel EF. The phlebotominae sand fly (Diptera: Psychodidae) fauna of two Atlantic rain forest reserves in the State of Rio de Janeiro, Brazil. Mem Inst Oswaldo Cruz. 2001;96:319-24.

34. Young DG, Duncan MA. Guide to the identification and geographic distribution of Lutzomyia sand flies in Mexico, the West Indies, Central and South America (Diptera, Psychodidae). Gainesville: Associated Publishers American Entomological Institute; 1994. (Mem. Amer. Entomol. Inst. no 54). Available from: http://www.dtic.mil/cgibin/GetTRDoc?Location=U2\&doc=GetTRDoc.pdf \&AD=ADA285737

Received: 1 March 2013

Accepted: 20 August 2013 